\title{
ORIGINALS
}

\section{The Effect of Dimethylbiguanide on Glucose Tolerance, Serum Insulin and Growth Hormone in Obese Patients*}

\author{
H. Schatz, S. Doct and R. HöFeR \\ 2nd Medical Department, University of Vienna, Vienna, Austria
}

Received: September 13, 1971, accepted: November 26, 1971

Summary. Glucose assimilation coefficient $\left(k_{G}\right)$, serum levels of immunoreactive insulin (IRI) and growth hormone (GH) were determined during an intravenous glucose load in 16 obese patients before treatment, after oral treatment with dimethylbiguanide for one week and after treatment for 10 weeks. - Patients were grouped according to their initial $k_{G}$-value: Group 1: 7 patients, $k_{G}>1.3$. Group 2: 7 patients, $k_{G}<1.3$. Group 3:2 patients with overt diabetes. - In group 1 mean values of $k_{G}$ showed no significant change under biguanide treatment, while initial hyperinsulinaemia was reduced to about one half after one week. In group 2 the mean value of $k_{G}$ increased significantly. Insulin levels, however, showed no uniform behaviour: Four patients showed a reduction and three patients an elevation. In group 3 a diminution of fasting blood glucose levels as well as a late decrease of reactive insulin levels was observed. Controls following withdrawal of the drug after 10 weeks revealed no significant changes of either $k_{G}$ or insulin levels compared with the original values. Mean values of growth hormone remained under $5 \mathrm{ng} / \mathrm{ml}$, decreasing during biguanide treatment in group 2. In most cases, dynamies of insulin secretion changed towards normal under therapy; in 3 cases, however, the peak level was delayed. - The investigations showed that an impaired intravenous glucose tolerance is normalized by treatment with dimethylbiguanide in obese patients without overt diabetes; furthermore, secretion of insulin and growth hormone is influenced by this therapy, mostly towards normal values. In several patients, however, an opposite behaviour was found. From our findings it can be concluded that changes of insulin levels under biguanide therapy cannot in all cases be caused by peripheral action of biguanides alone. As no significant long term effect of biguanide therapy could be shown, metabolic effects of the drug seem to occur only during its presence within the body.

Effet du diméthylbiguanide sur la tolérance au glucose, l'insuline du sérum et l'hormone de croissance chez des malades obèses

Résumé. Le coefficient d'assimilation du glucose $\left(\mathrm{k}_{\mathrm{G}}\right)$, les taux sériques d'insuline immunoréactive (IRI) et l'hormone de croissance (GH) ont été déterminés à l'occasion d'une charge de glucose par voie intra-veineuse chez 16 malades obèses avant traitement, après traitement oral d'une semaine au diméthylbiguanide et après traitement de 10 semaines. - Les malades ont été groupés selon leurs valeurs $\mathrm{k}_{\mathrm{G}}$ initiales: groupe 1: 7 malades, $\mathrm{k}_{\mathrm{G}}>1.3$. - groupe 2:7 malades, $\mathrm{k}_{\mathrm{G}}<1.3$. - groupe 3: 2 malades avec diabète établi. - Dans le groupe 1, les valeurs $k_{G}$ moyennes n'ont montré aucun changement significatif à la suite du traitement au biguanide, tandis que l'hyperinsulinémie initiale était réduite de moitié au

* Presented at the 5th Annual Meeting of the "Deutsche Diabetesgesellschaft", Bonn-Bad Godesberg, May 1970 . bout d'une semaine. Dans le groupe 2 , la valeur $\mathrm{k}_{\mathrm{G}}$ moyenne a augmenté de façon significative. Cependant, les taux d'insuline se comportent de façon différente: 4 malades ont montré une réduction et 3 malades, une augmentation. Dans le groupe 3, on a observé une diminution des taux de glucose du sang à jeun, de même qu'une diminution tardive des taux d'insuline réactive. Les contrôles effectués 10 semaines après la suppression du médicament n'ont montré aucun changement significatif de $\mathrm{k}_{\mathrm{G}}$ ou des taux d'insuline en comparaison avec les valeurs préthérapeutiques. Les valeurs moyennes de l'hormone de croissance ne dépassaient pas $5 \mathrm{ng} / \mathrm{ml}$, décroissant dans le groupe 2 sous l'effet du traitement au biguanide. Dans la plupart des cas, la sécrétion de l'insuline revenait à la normale sous traitement. Cependant, le maximum de la réaction était retardé dans 3 cas. - Les recherches ont montré que l'altération de la tolérance intraveineuse au glucose a été supprimée par le traitement au diméthylbiguanide chez les malades obèses sans diabète établi; de plus, la sécrétion d'insuline et d'hormone de croissance est influencée par ce traitement et tend le plus souvent vers des valeurs normales. Cependant, on note un comportement opposé chez plusieurs malades. A partir de ces observations, on peut conclure que le changement des taux d'insuline sous traitement au biguanide ne peut pas être causé dans tous les cas par la seule action périphérique des biguanides. Une action directe supplémentaire sur le pancréas est discutée. Etant donné qu'aucun effet significatif à long terme du traitement au biguanide n'a pu être montré, les effets métaboliques du médicament semblent être dus à sa concentration réelle.

Die Wirkung von Dimethylbiguanid auf Glucosetoleranz, Seruminsulin und Wachstumshormon bei Adipösen

Zusammenfassung. An 16 adipösen Patienten wurden der Glucoseassimilationskoeffizient $k_{G}$ sowie die radioimmunologisch meßbaren Serumspiegel von Insulin und Wachstumshormon während einer intravenösen Glucosebelastung 1 . vor, 2. nach einer Woche und 3. nach 10 Wochen peroraler Behandlung mit $2 \times 850 \mathrm{mg}$ Dimethylbiguanid bestimmt. - Die Patienten wurden nach dem ursprünglichen $k_{G}$. Wert in 3 Gruppen eingeteilt: Gruppe 1: 7 Patienten, $k_{G}>1.3$. Gruppe 2: 7 Patienten, $k_{G}<1.3$. Gruppe 3:2 Patienten mit manifestem Diabetes mellitus. - In Gruppe 1 ergab sich keine signifikante Änderung des Mittelwertes von $k_{G}$ durch die Biguanidtherapie, die ursprüngliche Hyperinsulinämie nahm nach einer Woche auf die Hälfte ab. In Gruppe 2 kam es nach einer Woche zu einem signifikanten Anstieg von $k_{G}$, die Insulinspiegel zeigten hier ein unterschiedliches Verhalten : Bei 4 Patienten wurde eine Senkung, bei 3 Patienten eine Erhöhung beobachtet. In Gruppe 3 fand sich nach einer Woche eine Senkung der Nüchternblutzuckerspiegel sowie eine Senkung der reaktiven Insulinspiegel in der Spätphase. Nach Absetzen des Medikamentes nach 10 Wochen waren in allen 3 Gruppen keine signifikanten Veränderungen gegenüber den Ausgangswerten nachweisbar. Die Mittelwerte 
der Wachstumshormonspiegel, die insgesamt unter $5 \mathrm{ng} / \mathrm{ml}$ blieben, ließen insbesondere in Gruppe 2 eine Abnahme unter Biguanidtherapie erkennen. Auffallend waren zeitliche Veränderungen der Sekretionsdynamik des Insulins, meist im Sinne einer Normalisierung; in. 3 Fällen kam es jedoch zu einer Verschiebung des reaktiven Maximums in die Spätphase. - Die Untersuchungen zeigter, daß bei übergewichtigen Patienten ohne manifesten Diabetes mellitus eine gestörte intravenöse Glucosetoleranz durch Dimethylbiguanid normalisiert wird und daß bei Adipösen die Insulin- und Wachstumshormonspiegel meist im Sinne einer Normali- sierung beeinflußt werden, wenn auch bei einzelnen $\mathrm{Pa}$ tienten ein gegensätzliches Verhalten gefunden wurde. Es ergaben sich Hinweise dafür, daß die Veränderungen der Insulinspiegel nicht immer allein durch eine periphere Biguanidwirkung verursacht sein dürften. Es ließ sich kein sicherer Langzeiteffekt von Dimethylbiguanid nachweisen, vielmehr erwies sich die aktuelle Konzentration des Pharmakons als stoffwechselwirksam.

Key words: Glucose tolerance, insulin, growth hormone, obesity, biguanide.
Previous studies of the effects of biguanides on glucose tolerance and insulin secretion have yielded conflicting results. Whereas several authors (Pomeranze et al. (1957), Abramson and Arky (1967)) observed an improved oral glucose tolerance in humans upon administration of biguanides, other workers (Fajans et al. (1960), Schilling (1959), Gutsche (1960)) failed to substantiate these reports. Studies of Czyzyk and Lawecki (1966) with diabetic patients indicated that biguanides may improve oral glucose tolerance without, however, affecting intravenous glucose tolerance (cf. also Berger (1968)). Analogous results were obtained by Hollobaugh (1970) with normal individuals. On the other hand, Bouaziz (1966) and Irsigler (1969) found that biguanides increased an initially pathological low glueose assimilation coefficient.

Grodsky et al. (1963) as well as Abramson and Arky (1967) reported that biguanides may lower increased reactive insulin levels following glucose administration. However, Jahnke et al. (1968) could not completely confirm these findings. Lefebvre (1968) found an elevation of reactive insulin levels after the administration of biguanides in 3 out of 15 cases.

These discrepancies might result in part from the different initial metabolic states of the patients, from the different ways of glucose administration and from the divergent diets, as well as from the different modes and durations of biguanide medication.

We therefore decided to study the effect of oral dimethylbiguanide administration on the intravenous glucose tolerance and the serum levels of insulin and growth hormone in obese patients as a function of the initial glucose tolerance and the duration of treatment.

\section{Materials and Methods}

We examined 16 obese patients who had contacted our clinic either because of their obesity or in the course of a routine occupational health control. 11 of the patients were male and 5 were female; their age varied between 18 and 53 years. Their weight was expressed as percentage of the average weight listed in the tables of the Metropolitan Life Insurance Company (Documenta Geigy, 7. Ed., Basel 1968, p. 701). All individuals were examined as out-patients. They continued in their usual jobs and were admonished to eat according to their normal habits. Dimethylbiguanide (metformin) was given orally in depot form $(2 \times 1$. tablet of $850 \mathrm{mg}$ each daily) for 10 weeks. Intravenous glucose loads $(0.33 \mathrm{~g}$ glucose $/ \mathrm{kg}$ body weight) were carried out in the morning on the fasted, resting patients 1. prior to the therapy, 2. after one week and 3. after 10 weeks. According to the diet history, each patient had ingested at least $250 \mathrm{~g}$ of carbohydrates during the 3 days prior to the examinations. For examination 2 after one week we administered one tablet $(850 \mathrm{mg})$ of dimethylbiguanide $2 \mathrm{~h}$ before the intravenous glucose load. The drug was withdrawn 3 days before examination 3 after 10 weeks. Three of the 16 patients refused to submit to this 3rd examination in the 10th week. The glucose was injected over 2 min into the left ante-cubital vein and blood was taken from the right arm before and after 5, 10, 20, $30,40,50$, and $60 \mathrm{~min}$. Blood glucose was determined according to the ferricyanide method (Hoffmann (1937)) in the autoanalyzer; the glucose assimilation coefficient $k_{G}$ was estimated according to Conard et al. (1953). Immunoreactive serum insulin was determined according to Melani et al. (1965), immunoreactive growth hormone by a double antibody method (Schalch and Parker (1964)).

\section{Results}

Table 1 lists the distribution of the patients into 3 groups according to their initial glucose assimilation coefficient; the table also includes the mean weights of the patients expressed as percentage of the norm. In group 1, biguanide did not affect the mean $k_{G}$ values either after 1 or after 10 weeks. In group 2 the $k_{G}$ value of each patient was increased after 1 week, resulting in a significant $(p<0.05)$ increase of the mean $k_{G}$ value. Three days after withdrawal of the drug in the 10th week this increase was no longer significant. The $k_{G}$ values of the 2 obese patients with overt diabetes showed only minor changes.

Fig. 1 illustrates the mean values of blood glucose, serum insulin and growth hormone during the 3 intravenous glucose loads. It can be seen that the 3 curves for blood glucose are essentially identical. On the other hand, the reactive hyperinsulinaemia decreased to about one half after the 1st week of therapy, as meas- 
ured by the area under the curve, the decrease of the insulin levels after $20 \mathrm{~min}(p<0.02)$ and $30 \mathrm{~min}$ $(p<0.01)$ being significant. Upon termination of the therapy after 10 weeks the insulin levels again approached their initial values. levels were below $5 \mathrm{ng} / \mathrm{ml}$ in all 3 examinations. The same was true for one of the 2 manifest diabeties. The levels tended to decrease during biguanide administration; in group 2 the decrease of the mean growth hormone level $60 \mathrm{~min}$ after glucose injection was

Table 1. Glucose assimilation coefficient $k_{G}$ and weight (as percentage of average weight) of three groups of obese patients, before, during and after treatment with dimethylbiguanide

\begin{tabular}{|c|c|c|c|c|}
\hline & & before & after 1 week & after 10 weeks \\
\hline \multirow[t]{3}{*}{$\begin{array}{l}\text { group } 1 \\
k_{G}>1.3, n=7\end{array}$} & $k_{G}$ & $\begin{array}{l}1.70 \\
1.62 \\
1.74 \\
1.58 \\
1.82 \\
1.92 \\
2.78\end{array}$ & $\begin{array}{l}0.91 \\
1.42 \\
1.70 \\
4.60 \\
1.62 \\
1.36 \\
1.73\end{array}$ & $\begin{array}{l}1.48 \\
-1.34 \\
- \\
1.36 \\
2.11 \\
1.40\end{array}$ \\
\hline & & $1.88 \pm 0.15$ & $\frac{1.91}{\mathrm{NS}}=0.46$ & $\begin{array}{l}1.54 \pm 0.15 \\
\mathrm{NS}\end{array}$ \\
\hline & $\begin{array}{l}\text { weight }(\%) \\
\bar{x} \pm \text { SEM }\end{array}$ & $132.3 \pm 5.4$ & $\begin{array}{l}132.1 \pm 5.3 \\
\text { NS }\end{array}$ & $\begin{array}{l}128.1 \pm 6.9 \\
p<0.05\end{array}$ \\
\hline \multirow[t]{3}{*}{$\begin{array}{l}\text { group } 2 \\
k_{G}<1.3, n=7\end{array}$} & $k_{G}$ & $\begin{array}{l}1.06 \\
1.18 \\
1.28 \\
0.72 \\
1.16 \\
1.12 \\
1.22\end{array}$ & $\begin{array}{l}1.98 \\
1.82 \\
1.39 \\
0.91 \\
1.45 \\
1.96 \\
1.83\end{array}$ & $\begin{array}{c}1.54 \\
3.00 \\
- \\
1.12 \\
1.06 \\
1.43 \\
1.62\end{array}$ \\
\hline & $\overline{\mathrm{x}} \pm \mathrm{SEM}$ & $1.10 \pm 0.07$ & $\underset{p<0.01}{1.62 \pm 0.15}$ & $\begin{array}{c}1.63 \pm 0.29 \\
\operatorname{NS}(0.05<p<0.1)\end{array}$ \\
\hline & $\begin{array}{l}\text { weight (\%) } \\
\overline{\mathbf{x}} \pm \text { SEM }\end{array}$ & $153.8+10.8$ & $\begin{array}{l}153.5 \pm 11.1 \\
\text { NS }\end{array}$ & $\underset{\mathrm{NS}}{154.1} \pm 109$ \\
\hline \multirow[t]{2}{*}{$\begin{array}{l}2 \text { manifest } \\
\text { diabetics }\end{array}$} & $k_{G}$ & $\begin{array}{l}0.60 \\
0.71\end{array}$ & $\begin{array}{l}0.66 \\
0.89\end{array}$ & $\begin{array}{l}0.77 \\
0.54\end{array}$ \\
\hline & weight (\%) & $\begin{array}{l}134.1 \\
1.42 .2\end{array}$ & $\begin{array}{l}136.3 \\
140.1\end{array}$ & $\begin{array}{l}131.6 \\
137.9\end{array}$ \\
\hline
\end{tabular}

$\overline{\mathrm{x}} \quad=$ mean

SEM $=$ standard deviation from the mean

NS $=$ not significant

The significance data refer to the difference between the experimental value and the value prior to therapy.

The results obtained with group 2 are summarized in Fig. 2. The significantly increased mean $k_{G}$ value after the first week (cf. Table 1) is reflected in the decreased mean levels of blood glucose. This decrease was significant both $30 \mathrm{~min}$ after glucose injection $(p<0.01)$ and after 40,50 or $60 \min (p<0.001)$. After 10 weeks the decrease was significant $(p<0.05)$ only after 40 and $50 \mathrm{~min}$. The insulin responses of the individual patients of group 2 were not uniform: after 1 week, 4 patients exhibited a decrease and 3 patients an unambiguous increase; the mean values did not differ significantly from each other.

The 2 obese patients with manifest diabetes mellitus had a lower fasting blood glucose value and, after 1 week, lower reactive insulin levels during the late phase of the glucose tolerance test (Fig. 3).

In groups 1 and 2 , the mean growth hormone significant both after 1 week and after 10 weeks $(p<0.05)$. In 5 (male) patients, the individual growth hormone levels were moderately increased during the glucose load; under biguanide administration, however, these levels became normal.

In the majority of the patients, administration of biguanide tended to normalize the time course of insulin secretion; in 9 out of 11 cases, the initially delayed peak of reactive insulin secretion occurred again 5 min after intravenous glucose injection under biguanide therapy. A different result was observed with 3 patients who had exhibited the most marked reactive hyperinsulinaemia $(>250 \mu \mathrm{U} / \mathrm{ml} 5 \mathrm{~min}$ after glucose injection) before the start of the therapy. In these 3 individuals, biguanides not only strongly lowered the insulin levels but also strongly altered the time course of the secretion process; the reactive 

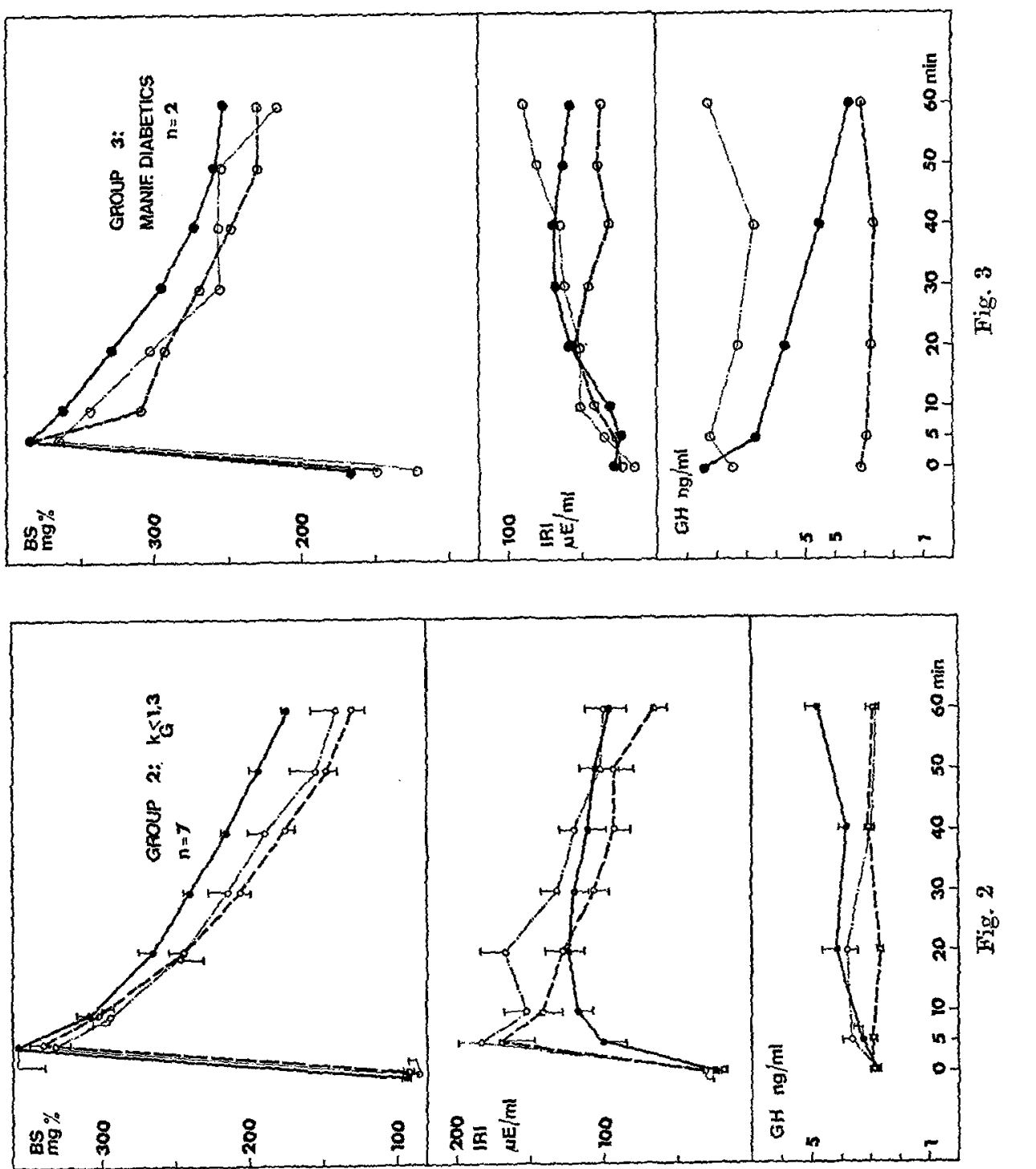

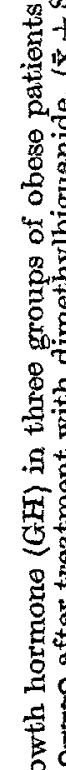

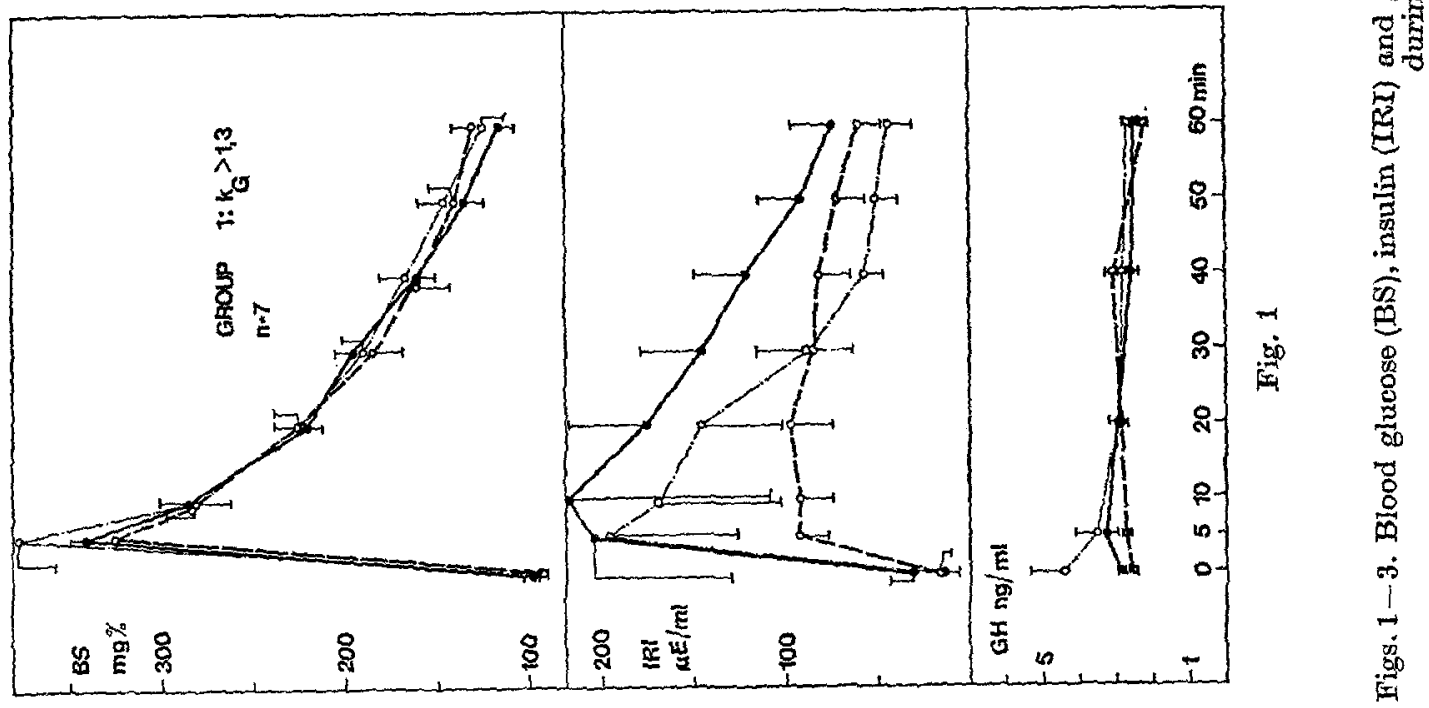


Vol. 8, No. 1, 1972

H. Schatz et al.: Effect of Dimethylbiguanide on Glucose Tolerance
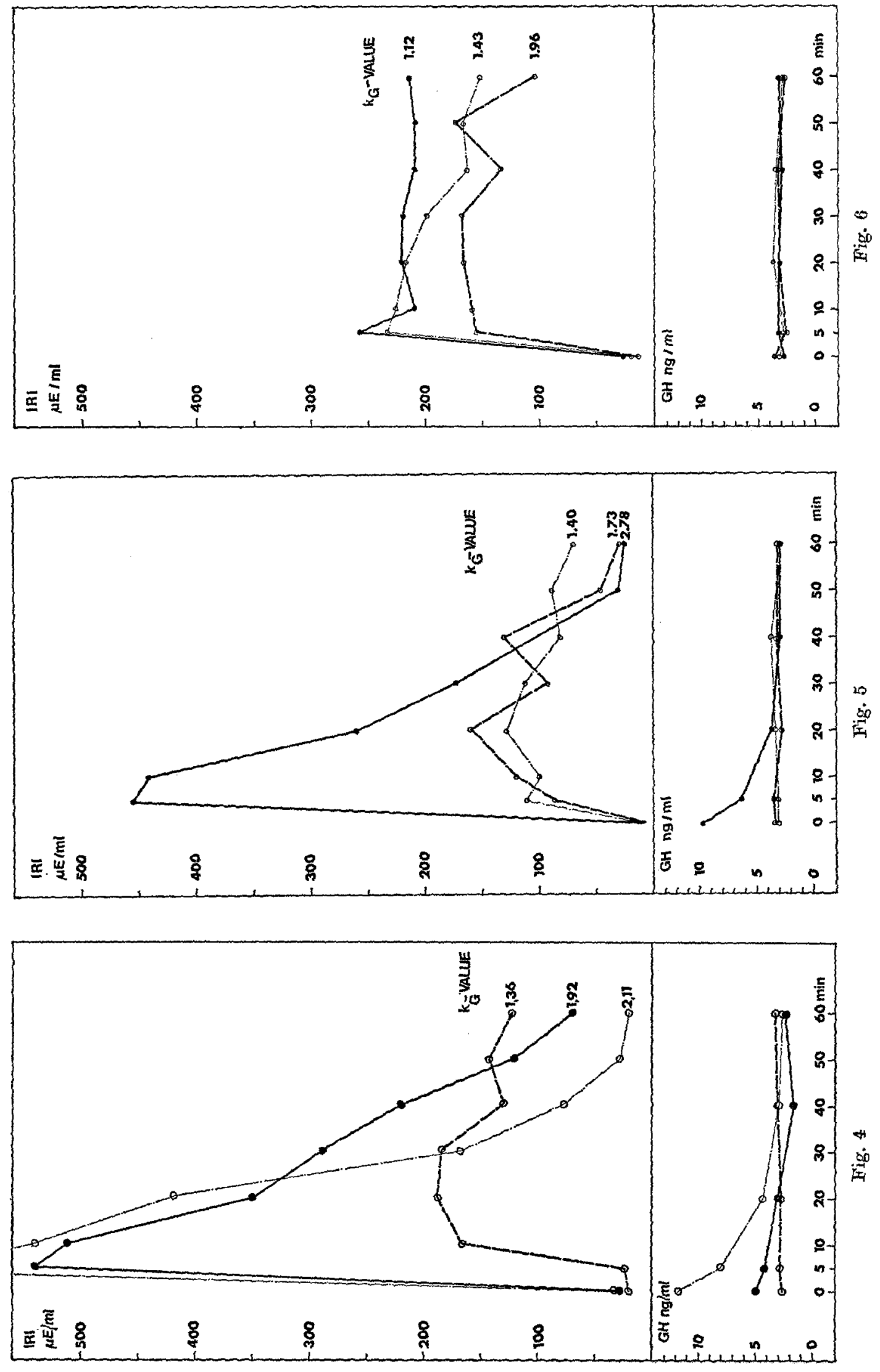
maximum was only reached after $20-40 \mathrm{~min}$ rather than after $5 \mathrm{~min}$ (Figs. $4-6$ ). In 2 patients the decrease of the insulin level was paralleled by a lowered $k_{G}$ value (Figs. 4 and 5 ).

\section{Discussion}

The present study shows that in obese patients without overt diabetes mellitus decreased intravenous glucose tolerance can be normalized by administration of dimethylbiguanide. This conclusion agrees with the data of Irsigler (1969). There is thus little doubt that, with these patients (group 2), dimethylbiguanide profoundly affects carbohydrate metabolism. The design of our experiments precludes the possibility (Czyzyk and Lawecki (1968), Kruger et al. (1970)) that biguanides improve glucose tolerance by inhibiting intestinal absorption of glucose. The significant increase of the glucose assimilation coefficient $k_{G}$, as observed in group 2 after 1 week, is not a consequence of altered body weight.

In contrast, the biguanide did not significantly affect the $k_{G}$ value in those obese patients who either suffered from manifest diabetes mellitus or whose intravenous glucose tolerance had initially been normal. The effect of biguanides on intravenous glucose tolerance is thus apparently modulated by the metabolic state. According to Hollobaugh et al. (1970), administration of biguanides to human controls with normal body weight alters neither intravenous glucose tolerance nor insulin secretion.

In obese patients with normal $k_{G}$ values we found a distinct decrease of the basal and the reactive hyperinsulinaemia. The most marked drop of insulin levels under biguanides occurred in those obese patients who had initially exhibited the greatest reactive hyperinsulinaemia (cf. also Boshell et al. (1968)). No clear-cut trend could be discerned in obese patients whose initially abnormal glucose tolerance had been corrected by biguanides; with this group, the mean values of the serum insulin levels did not differ significantly from the initial values. Our data, especially those of the individual patients in Figs. 4 and 5, indicate that the biguanide-induced decrease of the serum insulin levels is not necessarily accompanied by a decrease in the blood sugar levels. The present results do thus not merely reflect the recently documented peripheral effect of biguanides (Butterfield (1968)). At present we cannot explain how biguanides may alter the time course of insulin secretion or why they decreased or (in 3 of our patients) increased the insulin levels. Those questions might be approached by studying a possible effect of biguanides on the pancreas itself (Schatz et al. (1971a)).

In non-diabetic obese patients (group 1 and 2) the serum levels of growth hormone during intravenous glucose load remained, on the average, between 1 and $5 \mathrm{ng} / \mathrm{ml}$, group 2 exhibiting a slight increase. Administration of metformin tended to decrease the growth hormone levels; this effect became significant in group 2 during the late phase. In similar investigations on obese patients (involving oral glucose loads) Boshell et al. (1968) found that administration of phenformin did not alter the growth hormone levels which were on the average in the normal range; they observed, however, that biguanides blocked the increase of growth hormone levels induced by tolbutamide and arginine. In this context it is of interest that, in 5 of our patients, biguanides depressed the elevated growth hormone levels. Since these 5 patients were distributed among all 3 groups it is unlikely that there exists a direct connection between the biguanide-induced changes of glucose tolerance and growth hormone levels in obese patients as one could judge from the mean values in group 2. We had reached similar conclusions with patients suffering from liver cirrhosis (Schatz et al. (1971 b)).

Significant effects of biguanides were only observed at the 1 . control after 1 week; here $2 \mathrm{~h}$ before the i. $v$. glucose load the patients received one $850 \mathrm{mg}$ tablet of dimethylbiguanide in depot form. At the 2 . control after 10 weeks ( 3 days after the last biguanide administration) most of the initial parameters had been restored. There is thus no clearcut evidence for a long-term effect of the drug; rather, it appears that it is actual presence of the biguanide which leads to marked hormonal and metabolic changes in obese patients.

Acknowledgements. We wish to thank the Computer Centre of the Medical Faculty of the University of Vienna for statistical computations. Excellent technical assistance was provided by Mrs. H. Sinnek and Miss B. Steidler.

\section{References}

Abramson, E., Arky, R.A.: Treatment of the obese diabetic. A comparative study of placebo, sulfonylurea and phenformin. Metabolism 16, 204-212 (1967).

Berger, W.: Int. Biguanidsymposium, Rimini, October 1968.

Boshell, B.R., Roddam, R.F., MeAdams, G.L.: Effects of phenformin on insulin reserve and release. Ann. N. Y. Acad. Sci. 148, 756-767 (1968).

Bouaziz, P.J.: Rapport a l'étude de l'epreuve d'hyperglycemie provoquee par voie veineuse sous therapeutique antidiabetique. Thesis, Paris 1966.

Butterfield, W.: The effects of phenformin on peripheral glucose utilisation and insulin action in obosity and diabetes mellitus. Ann. N.Y. Acad. Sei. 148, 724-733 (1968).

Conard, V., Franckson, J.R.M., Bastenie, P.A., Kestens, J., Kovacs, L.: Etude critique du triangle d'hyperglycemie intraveineux chez l'homme normal a détermination d'un coefficient d'assimilation glucidique. Arch. int. Pharmacodyn. 93, 277-292 (1953).

Czyzyk, A., Lawecki, J.: Untersuchungen über den Einfluß von Phenyläthylbiguanid auf den Verlauf von Belastungsproben mit Insulin, Tolbutamid und Glucose beim Diabetes mellitus. Diabetologia 2, 62 - 68 (1966). - - Sadowski, J., Ponikowska, I., Szezepanik, Z. : Effect of biguanides on intestinal absorption of glucose. Diabetes 17, $492-498$ (1968). 
Fajans, S.S., Moorhouse, J.A., Doorenbos, H., Lawrence, H.L., Conn, J.W.: Metabolic effects of phenylethylbiguanide in normal subjects and in diabetic patients. Diabetes 9, 194-201 (1960).

Grodsky, G.M., Karam, J.H., Pavlatos, F.C., Forsham, P.H.: Reduction by phenformin of excessive insulin levels after glucose loading in obese and diabetic subjects. Metabolism 12, 278-286 (1963).

Gutsche, H.: Beeinflussung des Staub-Traugott-Effektes bei Biguanidbehandlung. In Bertram und Michael: Intern. Biguanid-Symposium, p. 102. Stuttgart: G. Thieme 1960 .

Hoffmann, W.S.: A rapid photoelectric method for the determination of glucose in the blood and urine. J. biol. Chem. 120, $51-55$ (1937).

Hollobaugh, S.L., Bhaskar Rao, M., Kruger, F.A. Studies on the site and mechanism of action of phenformin. I. Evidence for significant "nonperipheral" effects of phenformin on glucose metabolism in normal subjects. Diabetes 19, 45-49 (1970).

Irsigler, K.: Glukoseutilisation und Plasmalipoide bei adipösen Patienten unter dem Einfluß von Dimethylbiguanid (Glucophage). Wien. med. Wschr. 119, 191194 (1969).

Jahnke, K., Daweke, H., Liebermeister, H., Schilling, W., Grüneklee, D.: Über den Einfluß von Buformin auf das Verhalten von Gewicht und Stoffwechselmetaboliten bei Fettsüchtigen mit und ohne Störung der Glukosetoleranz. In: 2. Intern. Biguanid-Symposium, Düsseldorf 1967. Herausgegeben: von $\mathrm{K}$. Oberdisse, $\mathrm{H}$. Daweke und G. Michael, p. 82-91. Stuttgart: G. Thieme 1968 .

Kruger, F.A., Altschuld, R.A., Hollobaugh, S.L., Jewett, B.: Studies on the site and mechanism of action of phenformin. II. Phenformin inhibition of glucose transport by rat intestine. Diabetes 19, 50-52 (1970).
Lefebvre, P.: Intern. Biguanide Symposium, Rimini, October, 1968.

Melani, F., Ditschuneit, H., Bartelt, K., Friedrich, H., Pfeiffer, E.F.: Über die radioimmunologische Bestimmung von Insulin im Blut. Klin. Wschr. 43, 1000-1007 (1965).

Pomeranze, J., Fujiy, H., Mouratoff, G.T.: Clinical report of a new hypoglycemic agent. Proc. Soc. exp. Biol. 95, $193-194(1957)$.

Schalch, D.S., Parker, M.L.: A sensitive double antibody immunoassay for human growth hormone in plasma. Nature 203, 1141-1142 (1964).

Schatz, H. Katsilambros, N, Hinz, M., Pfeiffer, E.F.: Biguanidwirkung auf die Insulinsekretion isolierter Langerhansscher Inseln von Ratten. In: 2. Internatio. nales Donausymposium über Diabetes mellitus, Buda. pest 1971. Ed. I. Magyar and A. Beringer, p. 353-357. Wien: Verlag der Wiener Med. Akad. 1971 (a).

- Paumgartner, G., Brunner, H., Höfer, R., Grabner, G.: Seruminsulin und Wachstumshormon während Glukosebelastung bei Lebercirrhose. Wien. Z. inn. Med. 52, $41-46$ (1971) (b).

Schilling, I. : Ưber die orale Behandlung des Diabetes mellitus mit Biguaniden. I. und II. Mitteilung. Z. ges. inn. Med. 14, 705-711 (1959) und 14, 753-759 (1959).

Dr. H. Schatz,

Department of Endocrinology and Metabolism

Centre of Internal Medicine

and Pediatries,

University of $\mathrm{Ulm}$,

D-79 Ulm/Donau, Germany 